\title{
Studies on Degradation of Syntan used in Leather Tanning Process using Ozone
}

\author{
Rema. $^{* 1}$, B.Parivallal ${ }^{1}$ and R. Alwar Ramanujam ${ }^{1}$
}

\begin{abstract}
Degradation of syntan used in leather tanning process has been studied using ozone. Studies were carried out by varying operational parameters like initial syntan concentration, $\mathrm{pH}$ and ozone dose. The removal of COD, tannin and UV absorbing constituents has been determined. Degradation of syntan in terms of COD, Tannin and UV absorbing constituents was maximum at $\mathrm{pH} 7$.
\end{abstract}

\section{Index Terms-Ozone, COD, Tannin, UV254nm}

\section{INTRODUCTION}

Leather industry is one of the oldest industries in India and one of the leading foreign exchange earners for the country and has been characterised under the Red categoryThe most polluting industries. The tanneries are associated with the generation of huge amount of liquid effluent. The effluents generating from tanneries are complex waste induced by a series of chemical and biological activity to convert the collagen matrix of the skin/hide in to the leather having high concentration of pollutants and a great variety of composition, which results from changeability of technological processes conducted in tanneries.

Presence of refractory organic compounds like tannin in tannery wastewater imparts recalcitrance and toxicity. Synthetic tanning materials or syntan are high molecular organic compounds capable of rendering hides and skins into an imputrescible substance called leather. Most widely known syntans such as melamine based syntan, acrylic syntans are manufactured by treating aromatic substances, e.g., cresols, phenols, naphthalene, etc., with formaldehyde and sulphuric acid. Choice of the raw materials used in the manufacture of syntan depends mainly on nature of its applications. Syntans are not completely absorbed by the skin and remain in effluent. Constituent of syntan such as Phenol and formaldehyde are difficult to be degraded by biological treatment and found to be toxic to aquatic life1. Considering the refractory nature of tannin observed in the biological treatment, alternate methods involving advanced oxidation processes (AOPs) have been identified as a feasible option. Ozone treatment of several types of wastewater containing refractory compounds such as phenol, dyes, and pesticides has resulted in reduction in chemical oxygen demand (COD) 2,3,4,5. Ozonation of some biorefractory organic compounds like naphthaleine sulfonic acids can improve biodegradability and thereby allowing an appropriate sequencing of ozonation followed by an aerobic biological treatment step6.Study on the degradation of

${ }^{1}$ Environmental Technology Division, Central Leather Research Institute, Adyar, Chennai 600020, INDIA

* Corresponding author: Tele: +91-44-24450234 ; Fax +91-4424450234, email address: ranirema@gmail.com ( Rema.T) tannic acid by ozonation has reported total mineralization of tannic acid7.

Ozone decomposition in the aqueous solution gives rise to the formation of peroxide $\mathrm{HO} 2$ radicals, then hydroxyl $\mathrm{OH}$ radicals 8 :

$$
\begin{aligned}
& \mathrm{O}_{3}+\mathrm{H}_{2} \mathrm{O} \rightarrow \mathrm{HO}_{3}^{+}+\mathrm{OH}^{-} \\
& \mathrm{HO}_{3}++\mathrm{OH}^{-} \leftrightarrow 2 \mathrm{HO}_{2} \cdot \\
& \mathrm{HO}_{2} \cdot+\mathrm{O}_{3} \rightarrow \mathrm{OH}+2 \mathrm{O}_{2}
\end{aligned}
$$

The aim of the present study was to optimize the process condition for ozonation of syntan to be suitable for further treatment for safe disposal.

Degradation of syntan (aromatic sulfonic acid condensation product) used in the leather tanning process has been studied using ozone. Studies were carried out by varying operational parameters such as initial concentration of syntan, $\mathrm{pH}$ and Ozone dose. The removal of COD, Tannin and UV absorbing organic constituents has been determined.

\section{EXPERIMENTAL}

\section{A. Leather tannin}

Commercially available syntan (Aromatic sulfonic acid condensation product) containing 55-60\% tannin of $95 \%$ purity used in the leather manufacturing process was chosen for the study.

\section{B. Apparatus}

Ozonation experiment was carried out in a bench scale glass reactor of $40 \mathrm{~mm}$ diameter and $1600 \mathrm{~mm}$ height fitted with a ceramic diffuser for dispersion of ozone. A lab scale ozone generator (Faraday Model No .L6G, India) was used to supply ozone in the range of $1-6 \mathrm{~g} / \mathrm{hr}$ and ozone was produced from dry and pure oxygen generated from oxygen generator (Airsep, USA). The oxygen flow rate to the generator was maintained at $51 / \mathrm{min}$. The ozone concentration at the inlet and outlet of the reactor was determined by iodometric titration.

Ozone gas was passed through series of gas washing bottles containing $2 \% \mathrm{KI}$ solution. Ozone reacted with $\mathrm{KI}$ according to the following equations

$$
\mathrm{O}_{3}+2 \mathrm{KI}+\mathrm{H}_{2} \mathrm{O} \longrightarrow \mathrm{I}_{2}+2 \mathrm{KOH}+\mathrm{O}_{2}
$$

The concentration of the ozone in the inlet and outlet gas was measured by taking samples from the KI trap during each experimental run and titrating the iodine in the samples with $\mathrm{Na} 2 \mathrm{~S} 2 \mathrm{O} 3$ according to standard methods.

In order to study the effect of $\mathrm{pH}$ on degradation of syntan a series of experiments were conducted at $\mathrm{pH}$ of 5, 7 and 9 by adjusting $\mathrm{pH}$ using $0.1 \mathrm{~N} \mathrm{NaOH}$ and by adding 
appropriate phosphate and borate buffer to maintain it throughout ozonation. In order to study the effect of syntan concentration on degradation, syntan solutions of concentration $100,300,500,700 \mathrm{mg} / \mathrm{L}$ were used.

\section{Analytical methods}

Samples were withdrawn at predefined time intervals for a period of $60 \mathrm{~min}$ for COD, Tannin, and UV absorbance at $254 \mathrm{~nm}$ analysis according to procedures recommended in APHA manual9. $\mathrm{pH}$ was measured using $\mathrm{pH}$ meter. COD was determined by colorimetric technique after digesting the sample by closed reflux method. Tannin content was determined by tannin-Lignin methods according to standard methods. UV absorbance at $254 \mathrm{~nm}$ was determined using UV spectrophotometer (Hitachi, ModelU2000).

\section{RESUlT AND DisCUSSIONS}

\section{A. Effect of Initial syntan concentration}

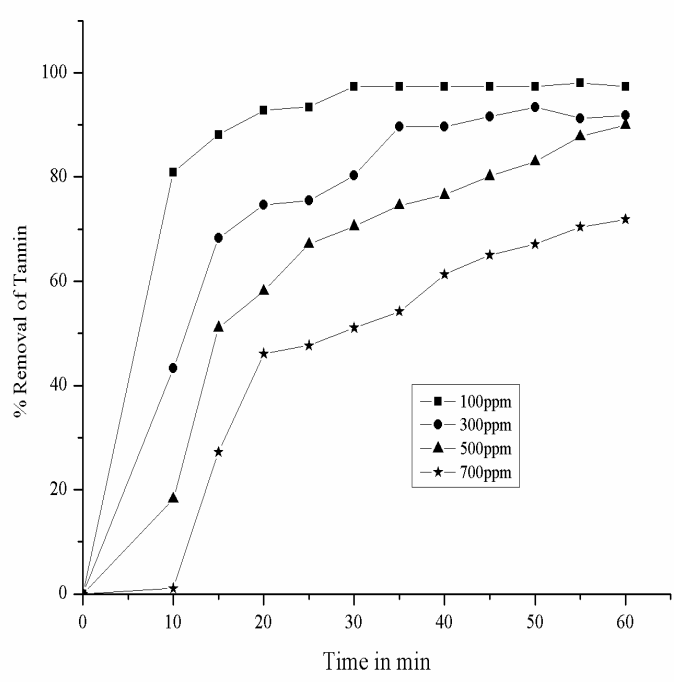

Fig 1 Degrdation of syntan at $\mathrm{pH}$ 7,ozone dose $1 \mathrm{~g} / \mathrm{hr}$

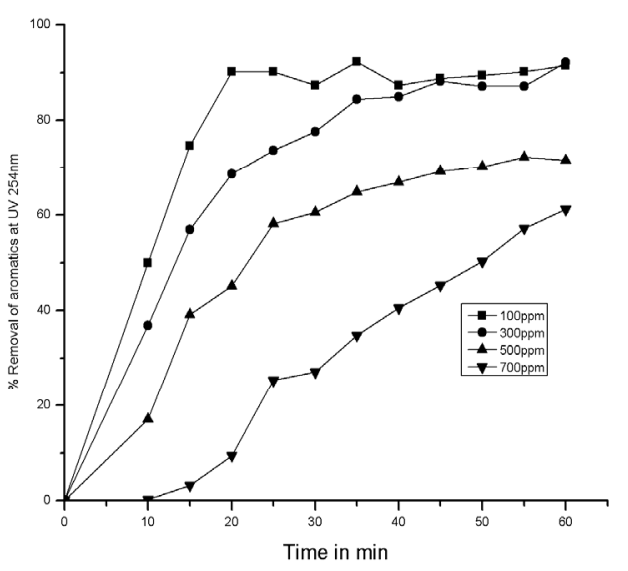

Fig 3 Degrdation of syntan at $\mathrm{pH} 7$,ozone dose $1 \mathrm{~g} / \mathrm{hr}$

\section{B. Effect of $p H$}

The study was carried out at $\mathrm{pH} 7$ by varying initial concentration from 100 to $700 \mathrm{ppm}$ with ozone dose of $1 \mathrm{~g} / \mathrm{hr}$. Figland 2 shows variation of tannin and COD with time during the ozonation of syntan at different initial syntan concentration. It was observed that syntan degradation was rapid at lower initial concentration as compared to other initial syntan concentrations. Fig.3 shows the reduction of UV absorbing constituents at UV 254nm during ozonation. Absorption in the ultraviolet range is dependent upon electronic structure of the molecule and at a wavelength of $254 \mathrm{~nm}$, is largely limited to conjugated carbon-carbon double bonds. COD, tannin and UV absorbing compounds removal decreases with increase in initial concentration.

At the end of $60 \mathrm{~min}$ tannin removal efficiency was $98 \%, 92 \%, 90 \%, 72 \%, \quad$ COD removal was $91 \%, 86 \%, 79 \%, 48 \%$ and UV absorbing constituents removal was $91 \%, 92 \%, 76 \%, 61 \%$ at a concentration of $100,300,500$ and 700ppm respectively.

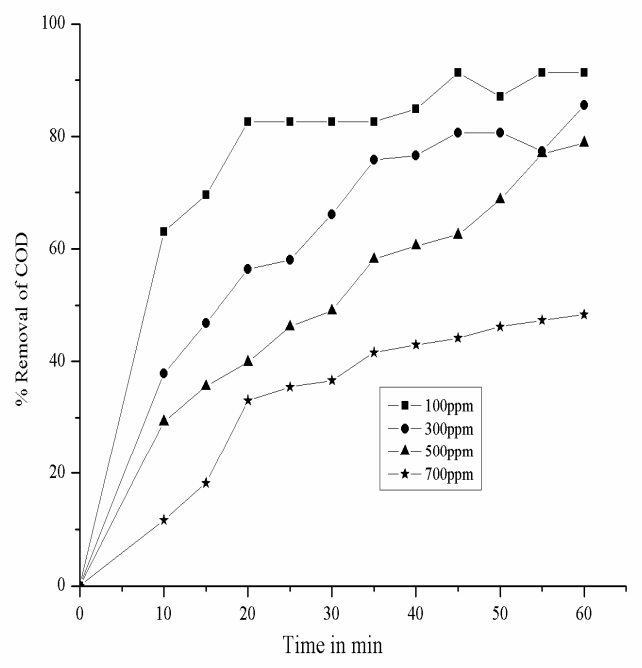

Fig 2 Degrdation of syntan at $\mathrm{pH}$ 7,ozone dose $1 \mathrm{~g} / \mathrm{hr}$

Fig 3and 4 depict the effect of initial $\mathrm{pH}$ on degradation of syntan in terms of removal of tannin, COD and UV absorbing compounds. Maximum removal was observed at $\mathrm{pH}$ 7. This shows that both molecular ozone and $\mathrm{OH}$ radical oxidation pathway, which becomes more pronounced at $\mathrm{pH} 7$ due to the accelerated ozone decomposition, play significant role in the degradation of syntan. The lower degradation of syntan at $\mathrm{pH} 9$ may be due the formation of oxygen ion during the rapid decomposition of ozone, whose reactivity is lower than that of hydroxyl radical10. Fig 5 indicate that reduction in UV $254 \mathrm{~nm}$ may be via oxidation of both $\mathrm{O} 3$ and $\mathrm{OH}$ pathways. This may be due to the hydroxyl radical preceded mainly on the aromatic moieties of the molecule. Similar observation has been reported in the study of ozonation of tertiary treated pharmaceutical wastewater 11. At the end of $60 \mathrm{~min}$ the removal of aromatics was $72 \%, 91 \%, 91 \%$ and the most effective removal of aromatics were attained at $\mathrm{pH} 7$. 


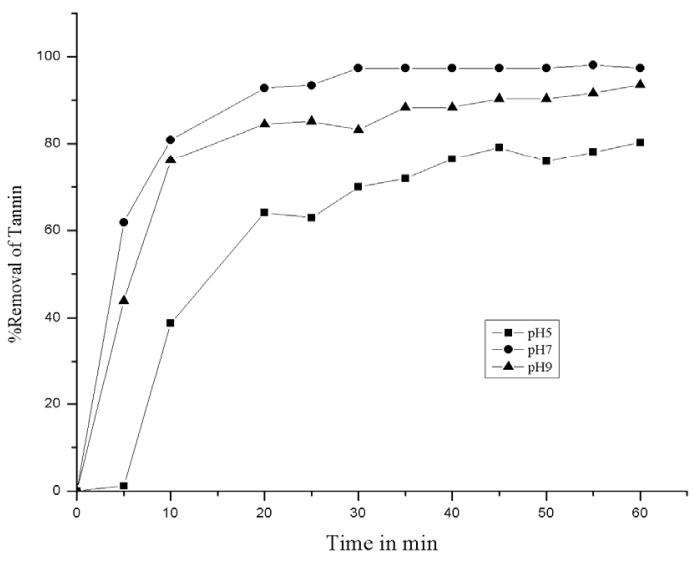

Fig 4 Degrdation of syntan in terms of tannin at concentration of 100ppm,ozone dose $1 \mathrm{~g} / \mathrm{hr}$

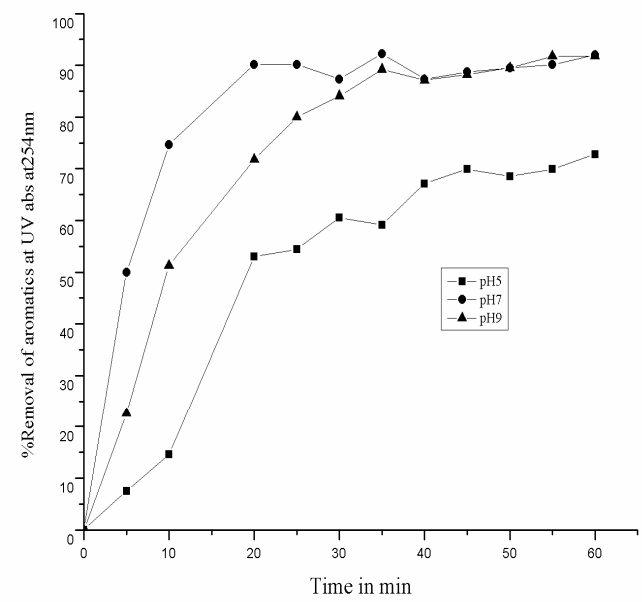

Fig 6 Degrdation of aromatics in syntan during ozonation at concentration $100 \mathrm{ppm}$, ozone dose $1 \mathrm{~g} / \mathrm{hr}$

\section{Ozone consumption on decomposition of syntan}

Initially ozone consumption has rapidly increased due to the destruction of readily degradable complex bonds present in the syntan (Fig 7). It is also observed from the trends shown in the graph that ozone consumption is related to $\mathrm{pH}$ up to $5 \mathrm{~min}$ and relatively independent after $50 \mathrm{~min}$. The ozone consumption between 5 and 50 minutes of reaction time vary due to variation in the concentration of various degraded products generated during ozonation process as the rate of reaction of ozone with such degraded products is $\mathrm{pH}$ dependent.

\section{CONCLUSION}

Experimental results of the study confirmed that ozonation is an effective process for treatment of synthetic tannin in the tannery wastewater. Maximum removal of $\mathrm{COD}$, tannin and aromatic compounds was achieved at $\mathrm{pH} 7$.

\section{ACKNOWLEDGMENT}

Authors wish to thank Director, Central Leather Research

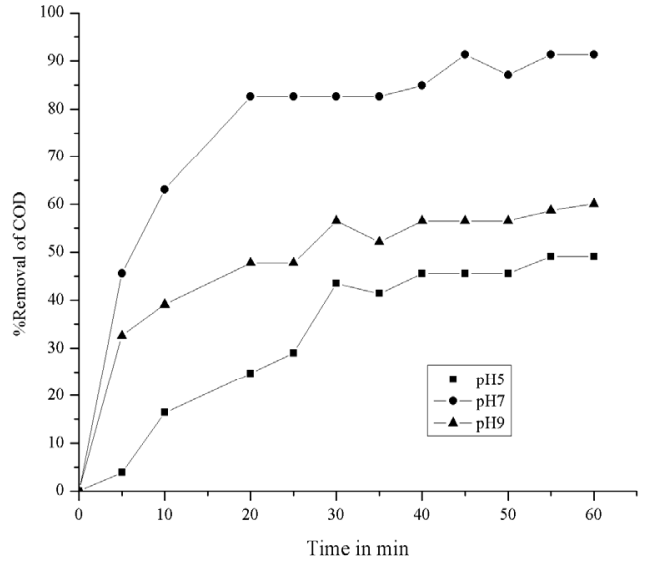

Fig 5 Degrdation of syntan in terms of tannin at concentration of 100ppm,ozone dose $1 \mathrm{~g} / \mathrm{hr}$

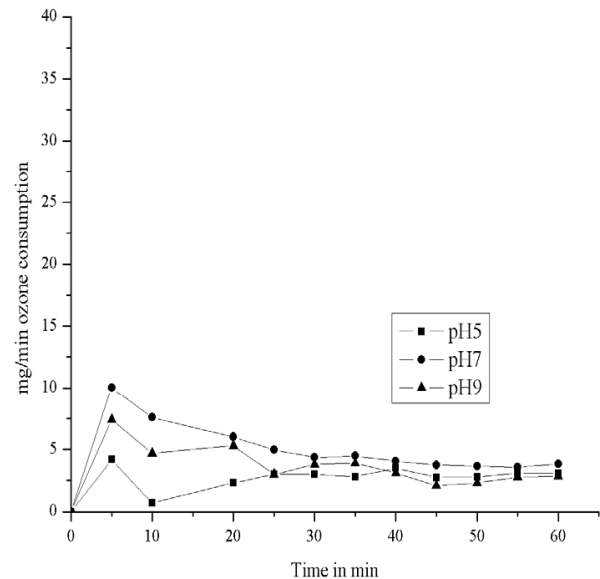

Fig.7 Ozone consumption rate for the degradation of syntan during ozonation at concentration 100ppm, ozone dose $1 \mathrm{~g} / \mathrm{hr}$

Institute, Adyar, and Chennai, India for the financial support and facilities provided for carrying out this research work.

\section{REFERENCE}

[1] T. Tisler and J. Zagorc-Koncan, Comparative assessment of toxicity of phenol, formaldehyde and industrial wastewater to aquatic organisms. Water, Air,Soil Poll.,vol 97, 1997, pp 315-322.

[2] V.M. Correia, T. Stephenson, and S.J. Judd, Characterization of textile wastewater-a review. Environ. Tech., vol15, 1994,pp 917929.

[3] P. Ormad, S. Cortes, A. Puig and J.L. Ovelleiro, Degrdation organochlorine compounds by $\mathrm{O}_{3}$ and $\mathrm{O}_{3} / \mathrm{H}_{2} \mathrm{O}_{2}$ Wat. Res., vol 31, 1997, pp 2387-2391.

[4] S.Baig,P.A and Lichits, Ozone treatment for biorefractory COD removal Water.Sci.Tech, Vol 43, issue 2, 2001,pp 197-204.

[5] K I Abe, K.Tanaka,Degrdation of phenol, asulam and lignin in aqueous solution by ozonation Toxico.environ.chem.Vol 54, 1996, pp 54-59.

[6] Y.Y., Win, M.U. Kumke, C.H.Specht, A.J.Schindelin, G.Kolliopoulos, G.Ohienbusch, G. Kleiser, S. Hesse, F.H.Frimmel, Influence of oxidation of dissolved organic matter (DOM) on subsequent water treatmentprocesses, Water Res, Vol 34, issue7, 2000 pp2098-2104. 
[7] J. Perkowski. U.Dawidow, W.K. Jozwiak. Advanced oxidation of tannic acid in aqueous solutions, Ozone Sci. Eng,Vol 25 Issue3,2002, pp199-209.

[8] J.,Perkowski, Lech Kos, Decoloration of Model dye house wastewater with advanced oxidation process. Fibres Text. East. Eur. July/September., 11:3, Vol 42 ,2003, pp 67-71.

[9] Standard methods, American public Health Assosician $20^{\text {th }}$ edition.

[10] S. Imamura, H. Umena, N. Kawabata and M. Teramoto. Ozonation of Organic Compounds in Alkaline Aqueous Media The Canadian Journal of chemical engineering, Vol 60, 1982, pp 853-858.

[11] EC. Wert.,F,L.Rosario-Ortiz., S. A.Synder, Using ultraviolet absorbance and color to assess Pharmaceutical Oxidation during Ozoantion of Wastewater Environ.Sci.Techno,.vol 43, 2009, pp4858-4863. 